\title{
Sistem Monitoring untuk Mesin Pelayanan Pelanggan (Studi Kasus di Etisalat Corporation, Abu Dhabi)
}

\author{
Bambang Santoso \\ Program Studi Teknik Informatika, Universitas Pamulang \\ Jln. Surya Kencana No. 1 Pamulang, Tangerang Selatan, Banten, Indonesia \\ e-mail: dosen01692@unpam.ac.id
}

\begin{abstract}
Customer service machines for a telecom operator are tools to prevent customers from churning (switching to another provider). So it is important to know the functional of these machines from time to time. These machines also help telecom operators to reduce the number of branch offices because the machines can indicate the existence of the operator without any branch office. Opening a branch office will cost more than machines because it has to rent a bigger place and more employees and equipments needed. However, sometimes these customer service machines have faults that some or all services cannot function well. For this the telecom operator requires another tool that will monitor the functional of the customer service machines. Another device called a monitoring system is required at all time to 'see' the existence of the machines. The monitoring system unfortunately cannot repair machines. If one machine is known to not function properly, then a technician is required to come and fix the machine. The monitoring system at any given interval polls the machines and requests its status. Afterward it writes the status in the database. Consequently, it is required to build an application interface that reads the database. The technicians can at any time see that status through an application program to find out if any machine requires attention. At the end of the week or at the end of the month technicians' supervisors can obtain uptime statistics of the machines. Statistics are required as a base of observation and review for future service improvements.
\end{abstract}

Keywords: Customer Service, Customer Service Machine, Monitoring System, supervisor, uptime statistics

\section{Pendahuluan}

Etisalat Corporation adalah perusahaan telekomunikasi di Persatuan Emirat Arab dengan jumlah pelanggan perorangan 11.6 juta dan pelanggan korporasi 300.000 . Jenis layanan yang diberikan Etisalat sangat beragam, dari telepon kabel, mobile (nir kabel), internet, TV kabel, media, komunikasi kapal dan lain-lain. Juga paket layanan seperti three-in-one yang terdiri dari internet, TV, dan telepon. Etisalat juga mempunyai kapal sebagai dukungan teknis kabel bawah laut yang menghubungkan Eropa, Afrika, dan Asia. (Etisalat Corporation, 2019)

Untuk melayani pelanggan Etisalat memasang banyak mesin pelayanan pelanggan di mana para pelanggan dapat melihat dan membayar tagihan telekom untuk pelanggan paska bayar, top up pulsa untuk pelanggan pra bayar, dan lain-lain.

Keberadaan mesin dianggap lebih murah daripada membuka sebuah kantor cabang. Karena pembukaan kantor cabang akan membutuhkan ruang yang lebih besar. Kantor membutuhkan karyawan yang akan mengisi kantor dan melayani pelanggan. Kantor juga membutuhkan perlatan pendukung seperti komputer, printer, mesin penghitung uang, dan sebagainya. Kantor juga membutuhkan furnitur lengkap seperti meja, kursi, lemari, brankas, partisi, karpet, dan lainnya. Di samping juga perlengkapan lain seperti kamar mandi, penerangan yang cukup, A/C, satpam, pembuatan logo, dan macam-macam perijinan.

Oleh sebab itu pemasangan mesin pelayanan pelanggan dinilai lebih ekonomis dalam segi keuangan, di samping dapat melayani pelanggan untuk transaksi-transaksi yang sering dilakukan. Juga sebagai bentuk keberadaan (existency) perusahaan di mana di tempat-tempat tertentu tidak dimungkinkan dibuat kantor cabang.

Ada 120 mesin pelayanan pelanggan yang tersebar di tujuh emirat di Persatuan Emirat Arab yaitu Abu Dhabi, Dubai, Sharjah, Ras Al Khaimah, Fujairah, Ummul Quwaim, dan Ajman. (Santoso, 2017)

Untuk dapat melihat seluruh status dari ke 120 mesin itu dibuatlah satu aplikasi yang dapat menampilkan status dari masing-masing mesin, 
misal OK, off line, kotak penyimpanan uang penuh, printer rusak, atau lainnya. Dengan melihat status, tim teknisi dapat segera ke lokasi jika diketahui ada mesin yang rusak. Jenis monitoring in disebut sebagai Available/Uptime Monitoring. (Smith, 2019). Monitor dibuat dengan tampilan GUI di atas platform Windows. (Shruti A. Kothalkar, 2016)

Di akhir periode, misal akhir pekan atau akhir bulan, supervisor dapat membuat laporan mengenai waktu layanan dari mesin (uptime). Laporan ini berguna untuk mengevaluasi kinerja dari tim teknisi, serta melakukan perbaikan cara kerja teknisi.

\section{Metode Penelitian}

Untuk dapat melihat status dari mesin, diperlukan software yang diletakkan di mesin yang akan menjawab request dari aplikasi monitoring. Software ini sudah disediakan di mesin pelayanan pelanggan oleh pembuat mesin. Penelitian ini bertugas membuat sistem yang akan memanggil (polling) software tersebut dari server monitoring, menterjemahkan jawaban untuk mengetahui status mesin, mencatat status dari mesin tersebut di dalam database. Melalui poll secara teratur ke mesin, sistem dapat mengetahui status semua mesin yang terhubung. Dengan demikian sistem dapat sebagai alat diagnostik mesin. (Alabi S.A., Adeosun O.O, 2015)

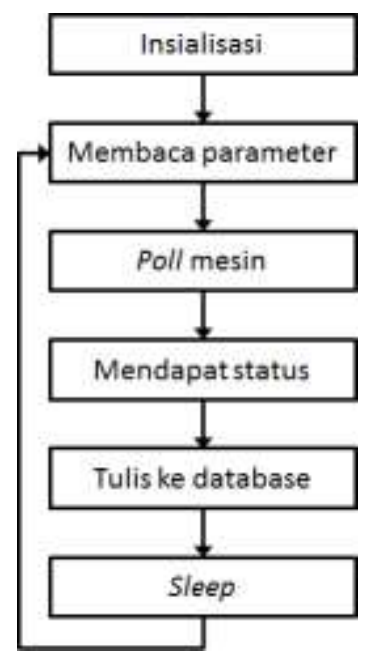

Gambar 1 Diagram alir dari sistem monitoring

\section{Lingkup Penelitian}

Penelitian meliputi mempelajari komunikasi ke mesin, format dari request dan response yang dipakai, menterjemahkan status, perancangan dan pembuatan database, daftar teknisi beserta wilayah penanganan, level teknisi, dan cara pengiriman SMS ke teknisi.

\section{Lokasi Penelitian}

Tempat penelitian berpusat di Abu Dhabi, Persatuan Emirat Arab, dengan beberapa kali kunjungan ke tempat mesin berada. Server nantinya akan diletakkan di pusat server yang dijaga 24 jam $\times 7$ hari, dengan $\mathrm{A} / \mathrm{C}$ dan pengaturan listrik yang cukup dengan didukung UPS dan generator yang telah disiapkan. Semua mesin pelayanan pelanggan telah terhubung ke jaringan sehingga server dapat mengakses seluruh mesin yang akan dimonitor.

\section{Teknologi yang Dipakai}

Untuk membangun aplikasi, bahasa pemrograman yang dipakai adalah $\mathrm{C}++$. (Kirchprinz \& Prinz, 2002) IDE yang dipakai adalah Visual Studio dari Microsoft. (Microsoft Corporation, 2019b). Database memakai Microsoft Access. (Microsoft Corporation, 2019a) Komunikasi antar thread dengan Windows Message. (Microsoft Corporation, 2019c)

Untuk disiplin Software Development Life Cycle dipakai model Waterfall karena model ini dianggap yang paling stabil dan konsisten untuk mendapatkan hasil yang telah disepakati bersama. Pemilik proyek adalah manajer PCPM (Public Cash Payment Machine) di mana beliau bertanggung jawab atas mesin pelayanan pelanggan mulai dari pembelian, pemeliharaan, peningkatan fungsi, dan pembuatan standard operating procedure (SOP) baik di dalam departemen PCPM maupun dalam hubungannya dengan bagian lain seperti bagian keuangan, customer service dan teknisi.

\section{Teknik Pengumpulan Data}

Pengumpulan data dimulai dengan wawancara dengan manajer PCPM, dengan teknisi dan dengan bagian keuangan. Studi pustaka dengan mempelajari buku panduan mesin pelayanan pelanggan, Windows Message dan Microsoft Visual Studio. Peneliti juga melakukan pengamatan lapangan dengan beberapa kali kunjungan ke tempat mesin berada.

\section{Tujuan Penelitian}

Tujuan penelitian adalah membantu teknisi dan pihak terkait melihat status mesin secara terpusat dengan waktu 'near real time' yaitu status beberapa detik sebelumnya. Diinginkan untuk membuat server di mana dapat dilakukan polling (mengirim permintaan status) ke mesin-mesin 
pelayanan pelanggan, menerima jawaban dari mesin, dan menuliskan status ke database. Status ini kemudian bisa dilihat secara terurut, dan dapat dibuat laporan statistik mesin termasuk berapa kali mesin rusak, berapa lama, dan berapa persen up time (waktu layanan) dari mesin.

Status tidaklah sangat real time. Karena polling dilakukan kira-kira setiap 10 detik sekali. Interval 10 detik dianggap cukup bagus karena aksi tanggapan dari teknisi juga tidak saat itu juga, biasanya dalam durasi satu jam teknisi akan bergerak ke lokasi jika ada masalah.

Manajer PCPM sangat membantu dalam pembuatan aplikasi, memberikan fasilitas yang diperlukan seperti server, software pendukung, akses ke mesin (dapat melakukan shutdown dan restart mesin bila diperlukan), dan pendekatan ke bagian lain terkait.

\section{Hasil dan Pembahasan}

Dari hasil pengumpulan data dapat disimpulkan bahwa sistem yang dibutuhkan adalah dengan rincian sebagai berikut.

1. Membuat polling ke semua mesin yang ada.

2. Menginterpretasikan jawaban mesin sehingga dapat diketahui status mesin saat itu.

3. Menyimpan status mesin ke basis data.

4. Membuat program aplikasi client sehingga teknisi dapat melihat status dari masingmasing mesin.

5. Diinginkan juga dapat membuat laporan mengenai uptime dari semua mesin. Laporan dapat dilakukan berkala seperti mingguan atau bulanan.

\section{Mesin Pelayanan Pelanggan}

Mesin pelayanan pelanggan yang dipakai Etisalat Corporation adalah suatu mesin yang berdiri sendiri (stand alone machine) yang dilengkapi dengan peralatan-peralatan untuk melayani kebutuhan pelanggan. Salah satu bentuk dari mesin adalah seperti pada

Bentuk tidak sama persis untuk semua mesin karena ada versi yang berbeda-beda dan ada perbedaan peralatan yang dikandung.

Semua mesin berjalan dengan sistem operasi Windows dari Microsoft. Hanya ketika aplikasi berjalan, sistem operasi terkunci sehingga pengguna tidak melihat interface seperti layaknya Windows.

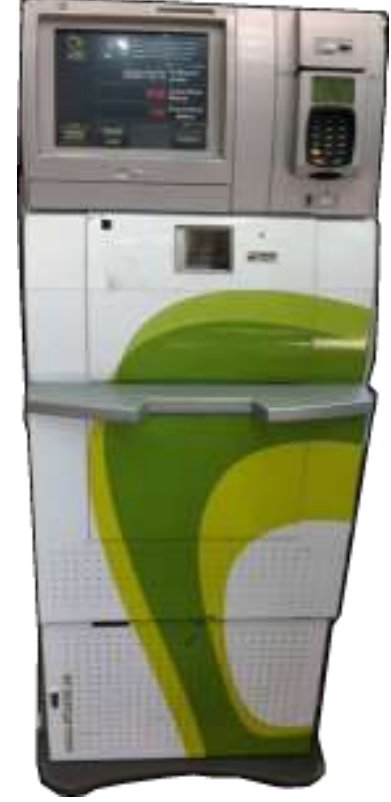

Gambar 2 Mesin pelayanan pelanggan Etisalat

Ada banyak modul aplikasi yang berjalan di mesin untuk dapat menjalankan fungsi Pelayanan Pelanggan. Modul yang berjalan adalah:

$$
\begin{array}{ll}
\text { - } & \text { Idle } \\
\text { - } & \text { Application } \\
\text { - } & \text { Printer } \\
\text { - } & \text { HostCom } \\
\text { - } & \text { Log }
\end{array}
$$

Antarmodul berkomunikasi dengan Windows Messages.

\section{Status Mesin}

Mesin menerima polling dari Sistem Monitoring, dan mesin memberikan jawaban. Jika tidak ada jawaban, maka mesin dianggap sebagai off line. Ini terjadi ketika mesin mati, rusak sama sekali, atau tidak terhubung ke jaringan.

Status mesin terdiri dari rangkaian byte (8bit). Tiap byte merefleksikan status dari satu peralatan di dalam mesin. Ada beberapa peralatan di dalam mesin sebagai mana Tabel 1 .

Tidak semua mesin Pelayanan Pelanggan mempunyai semua peralatan. Tergantung dari konfigurasi dari mesin, status dari peralatan dapat saja tidak terdefinisi (undefined) ketika peralatan tersebut memang tidak ada di mesin.

Setiap alat mempunyai satu byte sebagai status. Maka maksimum status yang bisa diberikan adalah 8 bit, di mana tiap bit bisa bernilai set (1) maupun reset (0). Bila satu byte tidak mencukupi maka dapat dibuat dua byte status untuk satu peralatan. 
Tabel 1 Peralatan dalam Mesin Pelayanan Pelanggan

\begin{tabular}{|c|c|c|}
\hline \multicolumn{3}{|r|}{ Pelanggan } \\
\hline No & Alat & Fungsi \\
\hline 1. & $\begin{array}{l}\text { Banknote } \\
\text { reader }\end{array}$ & $\begin{array}{l}\text { Pembaca uang, } \\
\text { menginterpresikan nilai } \\
\text { uang yang dimasukkan } \\
\text { pelanggan. Termasuk kotak } \\
\text { penyimpanan uang yang } \\
\text { dimasukkan pelanggan. }\end{array}$ \\
\hline 2. & $\begin{array}{l}\text { Receipt } \\
\text { printer }\end{array}$ & $\begin{array}{l}\text { Printer untuk mencetak } \\
\text { tanda bukti pembayaran } \\
\text { untuk pelanggan. }\end{array}$ \\
\hline 3. & $\begin{array}{l}\text { Journal } \\
\text { printer }\end{array}$ & $\begin{array}{l}\text { Printer untuk mencetak log } \\
\text { transaksi. Printer ini internal } \\
\text { di dalam mesin dan tidak } \\
\text { diberikan ke pelanggan. }\end{array}$ \\
\hline 4. & $\begin{array}{l}\text { Check } \\
\text { reader }\end{array}$ & $\begin{array}{l}\text { Pembaca cek. Termasuk } \\
\text { kotak penyimpanan cek. }\end{array}$ \\
\hline 5. & $\begin{array}{l}\text { Card } \\
\text { reader }\end{array}$ & $\begin{array}{lll}\text { Pembaca kartu. } & \text { Bisa } \\
\text { membaca data credit } & \text { card } \\
\text { maupun debit card. } & \\
\end{array}$ \\
\hline 6. & Serial port & $\begin{array}{l}\text { Koneksi serial yang } \\
\text { menghubungkan banyak } \\
\text { lampu di mesin, misal lampu } \\
\text { 'off' berwarna merah } \\
\text { menunjukkan ke pelanggan } \\
\text { bahwa mesin sedang tidak } \\
\text { bekerja, lampu printer hijau } \\
\text { berkedip-kedip } \\
\text { menunjukkan printer sedang } \\
\text { bekerja, dan lain-lain. }\end{array}$ \\
\hline
\end{tabular}
bit.

Berikut adalah status untuk masing-masing

Tabel 2 Status Banknote Reader

\begin{tabular}{|l|l|l|}
\hline Bit & Teks & Arti \\
\hline 0 & $\begin{array}{l}\text { Cash box nearly } \\
\text { full }\end{array}$ & $\begin{array}{l}\text { Kotak uang sudah } \\
\text { hampir penuh. Harus } \\
\text { segera dikosongkan }\end{array}$ \\
\hline 1 & $\begin{array}{l}\text { Banknote } \\
\text { reader sensor } \\
\text { covered }\end{array}$ & $\begin{array}{l}\text { Sensor tertutup, status } \\
\text { tidak diketahui }\end{array}$ \\
\hline 2 & Cash box full & $\begin{array}{l}\text { Kotak uang penuh. Tidak } \\
\text { dapat menerima } \\
\text { pembayaran lagi. }\end{array}$ \\
\hline 3 & $\begin{array}{l}\text { Banknote } \\
\text { reader jam }\end{array}$ & $\begin{array}{l}\text { Pembaca uang tidak } \\
\text { dapat bekerja, } \\
\text { kemungkinan ada uang } \\
\text { tersangkut di dalam }\end{array}$ \\
\hline 4 & $\begin{array}{l}\text { Other error on on } \\
\text { BanknoteReader }\end{array}$ & $\begin{array}{l}\text { Kesalahan lain di modul } \\
\text { BanknoteReader }\end{array}$ \\
\hline
\end{tabular}

Tabel 3 Status Receipt Printer

\begin{tabular}{|l|l|l|}
\hline Bit & Teks & Arti \\
\hline 0 & $\begin{array}{l}\text { Ticket printer } \\
\text { paper low }\end{array}$ & $\begin{array}{l}\text { Kertas di printer tanda } \\
\text { bukti sudah hampir habis. } \\
\text { Harus segera diganti. }\end{array}$ \\
\hline 1 & $\begin{array}{l}\text { Ticket printer } \\
\text { out of paper }\end{array}$ & $\begin{array}{l}\text { Kertas sudah habis. } \\
\text { Mesin tidak dapat } \\
\text { mencetak tanda bukti } \\
\text { untuk pelanggan. }\end{array}$ \\
\hline 2 & $\begin{array}{l}\text { Ticker printer } \\
\text { hardware } \\
\text { error }\end{array}$ & $\begin{array}{l}\text { Kesalahan di printer. } \\
\text { Tidak dapat mencetak. }\end{array}$ \\
\hline 3 & $\begin{array}{l}\text { Other error on } \\
\text { printer module }\end{array}$ & $\begin{array}{l}\text { Kesalahan lain di modul } \\
\text { Printer }\end{array}$ \\
\hline
\end{tabular}

Tabel 4 Status Journal Printer

\begin{tabular}{|l|l|l|}
\hline Bit & Teks & Arti \\
\hline 0 & $\begin{array}{l}\text { Journal } \\
\text { printer paper } \\
\text { low }\end{array}$ & $\begin{array}{l}\text { Kertas di printer sudah } \\
\text { hampir habis }\end{array}$ \\
\hline 1 & $\begin{array}{l}\text { Journal } \\
\text { printer out of } \\
\text { paper }\end{array}$ & Kertas di printer habis. \\
\hline 2 & $\begin{array}{l}\text { Journal } \\
\text { printer } \\
\text { hardware } \\
\text { error }\end{array}$ & $\begin{array}{l}\text { Kesalahan di printer. } \\
\text { Printer tidak dapat } \\
\text { mencetak journal. }\end{array}$ \\
\hline
\end{tabular}

Tabel 5 Status Card and Check Reader

\begin{tabular}{|l|l|l|}
\hline Bit & Teks & Arti \\
\hline 0 & $\begin{array}{l}\text { Card reader } \\
\text { jam }\end{array}$ & $\begin{array}{l}\text { Pembaca kartu tidak } \\
\text { dapat kerja, } \\
\text { kemungkinan ada kartu } \\
\text { di dalam }\end{array}$ \\
\hline 1 & $\begin{array}{l}\text { Other error on } \\
\text { Card reader }\end{array}$ & $\begin{array}{l}\text { Kesalahan lain di } \\
\text { pembaca kartu }\end{array}$ \\
\hline 2 & $\begin{array}{l}\text { Check reader } \\
\text { full }\end{array}$ & $\begin{array}{l}\text { Kotak di pembaca cek } \\
\text { penuh. } \\
\text { dikosongkan. }\end{array}$ \\
\hline 3 & $\begin{array}{l}\text { Check reader } \\
\text { jam }\end{array}$ & $\begin{array}{l}\text { Pembaca cek tidak dapat } \\
\text { bekerjar Kemungkinan } \\
\text { ada cek tersangkut. }\end{array}$ \\
\hline 4 & $\begin{array}{l}\text { Check reader } \\
\text { not operating }\end{array}$ & $\begin{array}{l}\text { Pembaca cek tidak dapat } \\
\text { beroperasi }\end{array}$ \\
\hline 5 & $\begin{array}{l}\text { Check reader } \\
\text { error }\end{array}$ & $\begin{array}{l}\text { Kesalahan di pembaca } \\
\text { cek }\end{array}$ \\
\hline 6 & $\begin{array}{l}\text { Hostcom } \\
\text { warning }\end{array}$ & $\begin{array}{l}\text { Modul HostCom } \\
\text { memberi lampu kuning }\end{array}$ \\
\hline 7 & Host off line & $\begin{array}{l}\text { Mesin tidak dapat } \\
\text { dihubungi }\end{array}$ \\
\hline
\end{tabular}


Tabel 6 Status Check Reader

\begin{tabular}{|l|l|l|}
\hline Bit & Teks & Arti \\
\hline 0 & $\begin{array}{l}\text { Check reader } \\
\text { full }\end{array}$ & $\begin{array}{l}\text { Kotak di pembaca cek } \\
\text { penuh. Harus } \\
\text { dikosongkan. }\end{array}$ \\
\hline 1 & $\begin{array}{l}\text { Check reader } \\
\text { jam }\end{array}$ & $\begin{array}{l}\text { Pembaca cek tidak dapat } \\
\text { bekerja Kemungkinan } \\
\text { ada cek tersangkut. }\end{array}$ \\
\hline 2 & $\begin{array}{l}\text { Check reader } \\
\text { not operating }\end{array}$ & $\begin{array}{l}\text { Pembaca cek tidak dapat } \\
\text { beroperasi }\end{array}$ \\
\hline 3 & $\begin{array}{l}\text { Check reader } \\
\text { error }\end{array}$ & $\begin{array}{l}\text { Kesalahan di pembaca } \\
\text { cek }\end{array}$ \\
\hline
\end{tabular}

Tabel 7 Status Host Communication

\begin{tabular}{|l|l|l|}
\hline Bit & Teks & Arti \\
\hline 0 & $\begin{array}{l}\text { Hostcom } \\
\text { warning }\end{array}$ & $\begin{array}{l}\text { Modul HostCom } \\
\text { memberi lampu kuning }\end{array}$ \\
\hline 1 & Host off line & $\begin{array}{l}\text { Mesin tidak dapat } \\
\text { dihubungi }\end{array}$ \\
\hline 2 & $\begin{array}{l}\text { Other error on } \\
\text { HostCom } \\
\text { module }\end{array}$ & $\begin{array}{l}\text { Kesalahan lain di modul } \\
\text { HostCom di mesin }\end{array}$ \\
\hline
\end{tabular}

Di samping peralatan, mesin pelayanan pelanggan sendiri mempunyai status secara umum sebagai mana tertera di bawah.

Tabel 8 Status Mesin 1

\begin{tabular}{|l|l|l|}
\hline Bit & Teks & Arti \\
\hline 0 & $\begin{array}{l}\text { Application } \\
\text { out of service }\end{array}$ & Kesalahan di aplikasi \\
\hline 1 & $\begin{array}{l}\text { Constantly } \\
\text { busy, possible } \\
\text { hang in } \\
\text { machine }\end{array}$ & $\begin{array}{l}\text { Selalu sibuk, mesin } \\
\text { tidak dapat dihubungi }\end{array}$ \\
\hline 2 & $\begin{array}{l}\text { Other error on } \\
\text { Application } \\
\text { module }\end{array}$ & $\begin{array}{l}\text { Kesalahan lain di modul } \\
\text { Application }\end{array}$ \\
\hline 3 & $\begin{array}{l}\text { Serial detector } \\
\text { signal }\end{array}$ & Kesalahan di port serial \\
\hline 4 & $\begin{array}{l}\text { Door opened } \\
\text { signal }\end{array}$ & Pintu mesin terbuka \\
\hline 5 & Alarm signal & Ada alarm di mesin \\
\hline
\end{tabular}

Tabel 9 Status Mesin 2

\begin{tabular}{|l|l|l|}
\hline Bit & Teks & Arti \\
\hline 0 & $\begin{array}{l}\text { Machine busy by } \\
\text { operator }\end{array}$ & $\begin{array}{l}\text { Ada teknisi sedang } \\
\text { bekerja di mesin }\end{array}$ \\
\hline 1 & Machine busy & $\begin{array}{l}\text { Mesin sedang melayani } \\
\text { pelanggan }\end{array}$ \\
\hline 2 & $\begin{array}{l}\text { Machine out of } \\
\text { service }\end{array}$ & Mesin tidak berfungsi \\
\hline 3 & Unknown status & $\begin{array}{l}\text { Tidak diketahui } \\
\text { statusnya }\end{array}$ \\
\hline
\end{tabular}

\begin{tabular}{|l|l|l|}
\hline 4 & $\begin{array}{l}\text { Other error on } \\
\text { Idle module }\end{array}$ & $\begin{array}{l}\text { Kesalahan lain di modul } \\
\text { Idle }\end{array}$ \\
\hline 5 & $\begin{array}{l}\text { Unable to } \\
\text { connect } \\
\text { machine }\end{array}$ & $\begin{array}{l}\text { Tidak dapat } \\
\text { berhubungan dengan } \\
\text { mesin }\end{array}$ \\
\hline 6 & $\begin{array}{l}\text { Out of service by } \\
\text { Telemaintenance }\end{array}$ & $\begin{array}{l}\text { Tidak dapat } \\
\text { menghubungi mesin, } \\
\text { sedang diservis oleh } \\
\text { teknisi. }\end{array}$ \\
\hline
\end{tabular}

\section{Perancangan Basis Data}

Status disimpan di dalam basis data untuk dapat nantinya dibuat laporan mengenai uptime dari masing-masing mesin. Tabel-tabel yang dibuat di basis data adalah sebagai berikut.

\section{Table Region}

Tabel ini memuat pembagian wilayah menurut Etisalat. Rincian struktur tabel Region dituliskan di Tabel 10 di bawah.

Tabel 10 Struktur Tabel Region

\begin{tabular}{|l|l|l|l|}
\hline No & Nama kolom & $\begin{array}{l}\text { Tipe } \\
\text { data }\end{array}$ & Keterangan \\
\hline 1. & RegionCode & Text & $\begin{array}{l}\text { Tiga huruf yang } \\
\text { melambangkan } \\
\text { kode region }\end{array}$ \\
\hline 2. & RegionAbbr & Text & $\begin{array}{l}\text { Dua huruf yang } \\
\text { dipakai sebagai } \\
\text { nama awal mesin }\end{array}$ \\
\hline 3. & RegionName & Text & $\begin{array}{l}\text { Nama region } \\
\text { secara lengkap }\end{array}$ \\
\hline
\end{tabular}

Meski pun ada tujuh emirat di Persatuan Emirat Arab, tetapi untuk keperluan mesin Pelayanan Pelanggan dibuat enam region/wilayah. Ini karena melihat instalasi mesin yang tidak sama banyak di setiap emirat. Keenam region yang didefinisikan adalah sebagai berikut.

Tabel 11 Isi Tabel Region

\begin{tabular}{|l|l|l|l|}
\hline No & $\begin{array}{l}\text { Region } \\
\text { Code }\end{array}$ & $\begin{array}{l}\text { Region } \\
\text { Abbr }\end{array}$ & RegionName \\
\hline 1 & ANR & AL & Al Ain \\
\hline 2 & AUR & AU & Abu Dhabi \\
\hline 3 & DXR & DX & Dubai \\
\hline 4 & ECR & EC & East Coast \\
\hline 5 & RAK & RA & Ras Al Khaimah \\
\hline 6 & WCR & SH & West Coast \\
\hline
\end{tabular}

Region Al Ain dan Abu Dhabi keduanya berada di Emirat Abu Dhabi, tetapi karena jumlah mesin banyak, maka dibagi menjadi dua region. 
East Coast adalah sebutan untuk Emirat Fujairah. Sedang West Coast adalah tiga Emirat digabung menjadi satu yaitu Emirat Sharjah, Ummul Quwaim dan Ajman.

RegionAbbr adalah singkatan region untuk dipakai di nama mesin. Untuk Abu Dhabi, semua nama mesin berawalan AU (AUPM001, AUPM002), untuk Dubai semua mesin berawalan DX (DXPM001, DXPM002) dan seterusnya.

\section{Tabel Machine}

Tabel ini berisi definisi mesin Pelayanan Pelanggan. Struktur dari tabel dirinci di Tabel 12. Region Code diambil dari tabel Region di atas.

Tabel 12 Struktur Tabel Machine

\begin{tabular}{|c|c|c|c|}
\hline No & Nama kolom & $\begin{array}{l}\text { Tipe } \\
\text { data }\end{array}$ & Keterangan \\
\hline 1 & RegionCode & Text & $\begin{array}{l}\text { Region di mana } \\
\text { mesin berada }\end{array}$ \\
\hline 2 & MachineName & Text & $\begin{array}{l}\text { Nama mesin, } \\
\text { primary key }\end{array}$ \\
\hline 3 & Description & Text & Keterangan \\
\hline 4 & IP & Text & $\begin{array}{l}\text { IP address dari } \\
\text { mesin. Jika } \\
\text { mesin memakai } \\
\text { DHCP, maka IP } \\
\text { address akan } \\
\text { dikosongkan. } \\
\text { Hubungan akan } \\
\text { memakai nama } \\
\text { mesin. }\end{array}$ \\
\hline 5 & Port & Num & $\begin{array}{l}\text { Port di mesin } \\
\text { untuk hubungan } \\
\text { socket. }\end{array}$ \\
\hline 6 & UserName & Text & $\begin{array}{l}\text { Username untuk } \\
\text { berhubungan } \\
\text { dengan mesin }\end{array}$ \\
\hline 7 & Pwd & Text & $\begin{array}{ll}\text { Password } & \text { dari } \\
\text { username, } \\
\text { dienkripsi }\end{array}$ \\
\hline 8 & Pwd2 & Text & $\begin{array}{l}\text { Password kedua. } \\
\text { Sementara tidak } \\
\text { dipakai }\end{array}$ \\
\hline 9 & Timeout & Num & $\begin{array}{l}\text { Berapa lama time } \\
\text { out }\end{array}$ \\
\hline 10 & Param1 & Num & Parameter satu \\
\hline 11 & Param2 & Num & Parameter dua \\
\hline 12 & $\begin{array}{l}\text { LastMonitorTi } \\
\text { me }\end{array}$ & $\begin{array}{l}\text { Date } \\
\text { Time }\end{array}$ & $\begin{array}{l}\text { Terakhir } \\
\text { berhubungan } \\
\text { dengan mesin }\end{array}$ \\
\hline 13 & LastResult & Num & Hasil terakhir \\
\hline 14 & LastStatus & Num & $\begin{array}{l}\text { Terjemahan } \\
\text { status terakhir }\end{array}$ \\
\hline
\end{tabular}

\begin{tabular}{|l|l|l|l|}
\hline 15 & $\begin{array}{l}\text { PrevMonitorTi } \\
\text { me }\end{array}$ & $\begin{array}{l}\text { Date } \\
\text { Time }\end{array}$ & $\begin{array}{l}\text { Waktu } \\
\text { berhubungan } \\
\text { yang sebelumnya }\end{array}$ \\
\hline 16 & PrevResult & Num & Hasil poll \\
\hline 17 & PrevStatus & Num & Terjemah status \\
\hline 18 & $\begin{array}{l}\text { TimeNotConn } \\
\text { ect }\end{array}$ & $\begin{array}{l}\text { Date } \\
\text { Time }\end{array}$ & $\begin{array}{l}\text { Waktu terakhir } \\
\text { tidak bisa } \\
\text { berhubungan } \\
\text { dengan mesin }\end{array}$ \\
\hline
\end{tabular}

\section{Tabel LogMachine}

Tabel ini berisi hasil dari poll ke mesin yang dilakukan oleh komponen Server.

Table log mesin mempunyai nama tabel sesuai dengan nama mesin. Misal mesin AUPM001 akan mempunyai tabel log bernama LogAUPM001. Karenanya nama mesin tidak dituliskan di kolom tabel.

Tabel 13 Struktur Tabel LogMachine

\begin{tabular}{|c|c|c|c|}
\hline No & Nama kolom & $\begin{array}{l}\text { Tipe } \\
\text { data }\end{array}$ & Keterangan \\
\hline 1. & LogTime & $\begin{array}{l}\text { Date } \\
\text { Time }\end{array}$ & \begin{tabular}{lr}
\multicolumn{2}{l}{ Tanggal dan waktu } \\
jawaban & poll \\
diterima & sistem \\
monitoring &
\end{tabular} \\
\hline 2. & $\begin{array}{l}\text { ConnectRes } \\
\text { ult }\end{array}$ & Num & $\begin{array}{l}\text { Hasil poll, berhasil } \\
\text { atau gagal }\end{array}$ \\
\hline 3. & Mstatus & Num & $\begin{array}{l}\text { Berisi status dari } \\
\text { mesin terjemahan } \\
\text { dari response. }\end{array}$ \\
\hline $\begin{array}{l}4 \\
\mathrm{~s} / \mathrm{d} \\
23\end{array}$ & $\begin{array}{l}\text { Err0 sampai } \\
\text { Err19 }\end{array}$ & Num & $\begin{array}{ll}\text { Byte status yang } \\
\text { diterima } & \text { dari } \\
\text { mesin, hasil dari } \\
\text { poll }\end{array}$ \\
\hline $\begin{array}{l}24 \\
\mathrm{~s} / \mathrm{d} \\
43\end{array}$ & $\begin{array}{l}\text { Per0 sampai } \\
\text { Per19 }\end{array}$ & Num & $\begin{array}{l}\text { Id dari peralatan di } \\
\text { mesin, kerkorespondensi } \\
\text { berkorr } \\
\text { dengan nomor Err } \\
\text { di kolom } \\
\text { sebelumnya }\end{array}$ \\
\hline 24 & Dhm5 & Num & $\begin{array}{l}\text { Jumlah pecahan } 5 \\
\text { Dirham di kotak } \\
\text { uang }\end{array}$ \\
\hline 25 & Dhm10 & Num & $\begin{array}{l}\text { Jumlah pecahan } 10 \\
\text { Dirham }\end{array}$ \\
\hline 26 & Dhm20 & Num & $\begin{array}{l}\text { Jumlah pecahan } 20 \\
\text { Dirham }\end{array}$ \\
\hline 27 & Dhm50 & Num & $\begin{array}{l}\text { Jumlah pecahan } 50 \\
\text { Dirham }\end{array}$ \\
\hline 28 & Dhm100 & Num & $\begin{array}{l}\text { Jumlah pecahan } \\
\text { 100 Dirham }\end{array}$ \\
\hline 29 & Dhm200 & Num & $\begin{array}{l}\text { Jumlah pecahan } \\
\text { 200 Dirham }\end{array}$ \\
\hline
\end{tabular}




\begin{tabular}{|l|l|l|l|}
\hline 30 & Dhm500 & Num & $\begin{array}{l}\text { Jumlah pecahan } \\
\text { 500 Dirham }\end{array}$ \\
\hline 31 & Dhm1000 & Num & $\begin{array}{l}\text { Jumlah pecahan } \\
\text { 1000 Dirham }\end{array}$ \\
\hline
\end{tabular}

Dirham adalah mata uang Persatuan Emirat Arab. Pecahan mata uang kertas yang beredar adalah 5, 10, 20, 50, 100, 200, 500, dan 1000 Dirham. Mesin melalui banknote reader dapat mengenali uang yang diterima, dan ini dijadikan dasar penetapan berapa dirham uang tunai yang dimasukkan oleh pengguna.

Meski pun ada mata uang koin untuk pecahan kecil, mesin tidak menerima koin. Karenanya tidak didefinisikan pecahan kecil $(0.25,0.5$, maupun 1 Dirham) di banknote reader.

\section{Tabel User}

Berisi nama-nama user yang dapat login ke sistem. Struktur tabel terinci di Tabel 14 di bawah.

Tabel 14 Struktur tabel User

\begin{tabular}{|l|l|l|l|}
\hline No & Kolom & $\begin{array}{l}\text { Tipe } \\
\text { data }\end{array}$ & Keterangan \\
\hline 1 & RegionCode & Text & Kode region \\
\hline 2 & UserName & Text & ID untuk login \\
\hline 3 & FullName & Text & Nama lengkap \\
\hline 4 & Pwd & Text & Kata kunci \\
\hline 5 & Dept & Text & Departemen \\
\hline 6 & LastLogin & $\begin{array}{l}\text { Date } \\
\text { Time }\end{array}$ & $\begin{array}{l}\text { Waktu terakhir } \\
\text { login }\end{array}$ \\
\hline
\end{tabular}

\section{Menterjemahkan Status}

Untuk byte berisi nol, maka status dari alat tersebut adalah baik (OK) yang berarti baik dan mesin berfungsi normal. Jika tidak sama dengan nol, maka dilihat bit mana yang di-set dalam jawaban mesin. Untuk melihat bit mana yang diset oleh mesin (pertanda ada masalah), dipakai algoritma berikut.

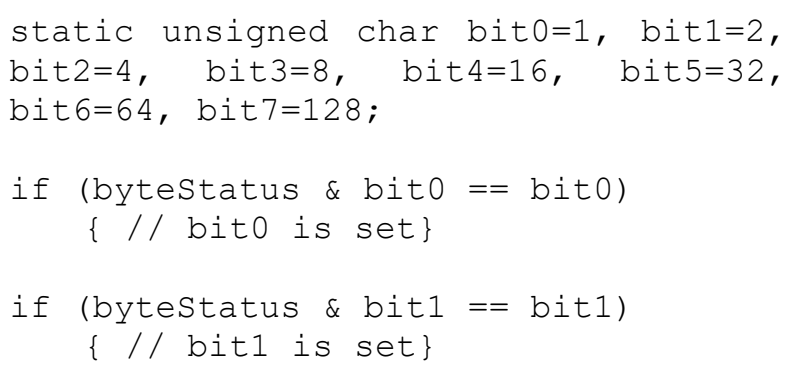

Dan seterusnya. Tiap bit independen terhadap bit lain, yaitu tiap bit dapat di-set atau pun di-reset tanpa tergantung dari status bit yang lain.
Tiap peripheral (peralatan) dalam mesin mempunyai status masing-masing yang tidak sama satu sama lain. Karenanya, status tiap peralatan berbeda meskipun bit kesalahan di posisi yang sama.

\section{Diagram Sistem Monitoring}

Error! Reference source not found. menunjukkan diagram koneksi Sistem Monitoring yang dipakai. Hubungan memakai infrastruktur yang sudah ada di Etisalat Corporation.

Diagram merupakan diagram logical. Secara physical, ada banyak router, hub maupun gateway yang membantu. Sebagian mesin ada di jaringan intranet Etisalat di mana mesin berada di kantor Etisalat. Sebagian mesin lagi berada di luar jaringan intranet seperti di mall atau di tempattempat umum lain.

Untuk keamanan, di tempat-tempat umum dipasang mesin enkripsi sehingga transmisi tidak dapat dibaca jika pun terekspos ke luar. Untuk masuk ke intranet, jaringan luar harus melalui firewall untuk menjaga keamanan.

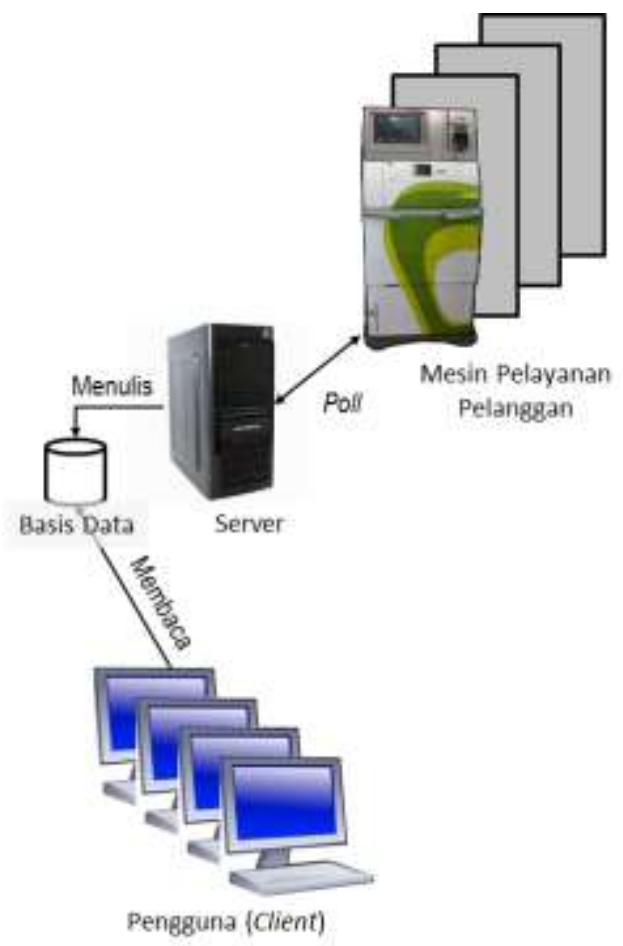

Gambar 3 Diagram Sistem Monitoring

\section{Berhubungan Dengan Mesin}

Secara software, hubungan dengan mesin dibantu dengan satu dll (Dynamic Link Library) yang diberikan oleh pembuat mesin. Dengan memakai dll tersebut, sistem monitoring dapat melakukan poll ke mesin dan mendapatkan jawaban dari mesin. 
Dynamic Link Library ini berhubungan dengan mesin melalui socket TCP/IP. Dll memformat request dari Sistem Monitoring sehingga pesan dapat dibaca oleh mesin. Mesin menjawab dengan response yang juga mengikuti satu format tertentu. Response ini diberikan dari dll ke Sistem Monitoring untuk diterjemahkan.

\section{Thread}

Thread dalam sistem digunakan untuk melakukan pengulangan permintaan status ke semua mesin. Thread dijalankan setiap 10 detik untuk melakukan poll ke mesin satu per satu. Poll yang terlalu cepat juga tidak banyak berguna karena membebani server dan teknisi tidak akan melihat status mesin setiap detik. Sepuluh detik dianggap waktu ideal antar poll.

Interval ini dapat berubah ketika poll ke mesin terhambat adanya mesin yang tidak menjawab. Semakin banyak mesin tidak menjawab, akan semakin lama pengulangan poll ke masing-masing mesin.

\section{Kesimpulan}

Penelitian menghasilkan dua aplikasi, yaitu client dan server. Aplikasi server berjalan di ruang komputer, 24 jam x 7 hari, tidak memerlukan antar muka (user interface), semua kejadian ditulis ke suatu file yang bisa dilihat tiap saat oleh administrator. Tugas server adalah melakukan poll ke mesin dan menuliskan jawaban ke basis data.

Aplikasi client dapat dijalankan dan dimatikan setiap saat oleh pengguna. Aplikasi ini mengakses basis data yang telah ditulis oleh server. Tidak ada hubungan langsung dari client ke server. Server dapat dimatikan tanpa mempengaruhi client. Aplikasi client dipakai oleh teknisi maupun pihak lain untuk melihat status mesin.

Hasil dari penelitian telah dipasang dan sistem dapat mengirim poll dan menerima jawaban dari sekitar 120 mesin. Hasil status dapat diinterpresikan dengan benar. Rata-rata interval antara satu poll ke poll yang lain adalah 10 detik. Waktu 10 detik dianggap layak sebagai interval antar poll. Penulisan di basis data juga berhasil dengan baik sehingga laporan mingguan maupun bulanan dapat dibuat oleh para teknisi.

Secara umum, tingkat respon dari teknisi membaik karena di samping mereka dapat melihat status mesin secara 'near real time', supervisor dapat melihat hasil uptime dari mesin. Uptime yang besar dari mesin dianggap sebagai prestasi dari teknisi. Dengan adanya laporan ini dapat di- review dan diperbaiki cara kerja teknisi bagi mesin-mesin yang uptime mesin-mesinnya rendah. Uptime dari mesin juga dapat dijadikan KPI (Key Performance Indicator) dari para teknisi.

\section{Saran}

Diharapkan Sistem Monitoring dapat memberikan notifikasi ke teknisi ketika ada mesin yang rusak. Sehingga teknisi tidak setiap saat harus membuka aplikasi client untuk melihat apakah ada mesin yang memerlukan perhatian.

\section{Referensi}

Alabi S.A., Adeosun O.O, O. T. D. (2015). Development of a Proactive Fault Diagnosis for Critical System. Information and Knowledge Management, 5(3), 1-36.

Etisalat Corporation. (2019). Etisalat Corporation. Retrieved October 5, 2019, from website website: https://etisalat.com/en/about/profile/companyprofile.jsp

Kirch-prinz, U., \& Prinz, P. (2002). A Complete Guide to Programming in $C++$ (1st ed.). Sudbury, MA: Jones And Bartlett Publishers.

Microsoft Corporation. (2019a). Microsoft Access. Retrieved October 3, 2019, from website website: https://products.office.com/en-us/access

Microsoft Corporation. (2019b). Microsoft Visual Studio. Retrieved October 4, 2019, from website website: https://visualstudio.microsoft.com/

Microsoft Corporation. (2019c). Window Messages. Retrieved October 5, 2019, from website website: https://docs.microsoft.com/idid/windows/win32/learnwin32/window-messages

Santoso, B. (2017). Fitur Notifikasi untuk Sistem Monitoring Mesin Pelayanan Pelanggan (Studi Kasus di Etisalat Corporation, Abu Dhabi). Jurnal Informatika Universitas Pamulang, 2(2), 81-87. Retrieved from http://openjournal.unpam.ac.id/index.php/inform atika/article/view/1509

Shruti A. Kothalkar, A. S. J. (2016). A Review on Atmospheric Parameter Monitoring System for SMART CITIES using Internet. International Journal Of Engineering And Computer Science, 5(17322), $17322-17328$ https://doi.org/10.18535/ijecs/v5i7.25

Smith, C. (2019). The 7 Main Types of Server Monitoring. Retrieved October 5, 2019, from KnowTechie website: https://knowtechie.com/the-7-main-types-ofserver-monitoring/ 